DOI: 10.46340/eujem.2020.6.3.3

Maryna Homon

ORCID iD : http://orcid.org/0000-0002-1075-408X

Simon Kuznets Kharkiv National University of Economics, Ukraine

\title{
FORMATION AND REALIZATION \\ OF STATE REGULATION POTENTIAL OF ENTERPRISES INNOVATIVE ACTIVITY
}

\author{
Марина Гомон

\section{ФОРМУВАННЯ ТА РЕАЛІЗАЦІЯ ПОТЕНЦАЛУ ДЕРЖАВНОГО РЕГУЛЮВАННЯ ІННОВАЦЙНОЇ ДІЯЛЬНОСТІ ПІДПРИСМСТВ}

Харківський національний економічний університет імені Семена Кузнеця, Україна

The article develops a methodological approach to the formation and implementation of the potential of state regulation of innovation activities of enterprises. The principles of realization of the potential of state regulation of innovative activity of enterprises are formed. The structure of the potential of state regulation of innovative activity of enterprises in the form of target, subjective, organizational, and instrumental components is determined. A three-component model of realization of the potential of state regulation of innovative activity of enterprises has been formed, which will allow making a reasonable decision on the introduction and realization of effective tools of state regulation taking into account its expediency, efficiency, and effectiveness.

Keywords: potential, state regulation, innovative activity, model of realization, enterprise.

Постановка проблеми. Досвід високорозвинених країн показав, що розвиток національної економіки на інноваційній основі сприяє підвищенню конкурентоспроможності та зростання рівня добробуту населення.

Однак, для України інноваційний розвиток не став однією з головних характеристик зростання національної економіки. Спостерігалися протягом кількох років і позитивні тенденції, але вони мали переважно тимчасовий характер і змінювалися слабкими зрушеннями в економіці, що характеризує інноваційні процеси в Україні як нестійкі та позбавлені чітких довготермінових стимулів для інноваційної діяльності.

Постає необхідність уналежну методологічну, техніко-технологічну та ресурсному забезпеченні, інакше неможливо повною мірою використати потенціал національної економіки. Ефективного результату не можна досягти без регульованої ролі держави, тому варто дослідити потенціал державного регулювання інновацій.

Аналіз останніх досліджень i публікацій. Значну увагу дослідженню теоретичних i практичних аспектів державного регулювання інноваційного розвитку приділено в працях таких науковців, як Амоша О. І., Андрощук О. В, Антонюк Л. Л., Гаман М. В., Геєць В. М., Ілляшенко С. М., Крупка М. І., Федосов В. М., Федулова Л. І., та інші.

Однак, незважаючи на значний здобуток наукових праць, дослідження питання формування та реалізації потенціалу державного регулювання в сфері інноваційної діяльності підприємств немає достатнього наукового обгрунтування.

Формулювання цілей статті. Метою статті є розробка методичного підходу до формування та реалізації потенціалу державного регулювання інноваційної діяльності підприємств на основі обгрунтування інструментів державного регулювання їхнього інноваційного розвитку.

Виклад основного матеріалу дослідження. Оцінювання потенціалу державного регулювання інноваційної діяльності підприємств дозволить мінімізувати суб'єктивний вплив та дати об'єктивну картину перспектив державного регулювання інноваційної діяльності в Україні. 3 цією метою у статті запропоновано методичний підхід до формування та реалізації потенціалу державного регулювання інноваційної діяльності підприємств, який складається із трьох блоків (рис. 1). 


\begin{tabular}{|c|c|}
\hline $\begin{array}{l}\frac{1}{5} \\
\frac{1}{0} \\
\frac{1}{6}\end{array}$ & $\begin{array}{c}\text { Формування інформаційного простору для визначення } \\
\text { структури потенціалу державного регулювання інноваційної } \\
\text { діяльності підприємств }\end{array}$ \\
\hline & $\begin{array}{c}\text { Kpuтерій 1. Наявність законодавчого та організаційно- } \\
\text { функціонального забезпечення }\end{array}$ \\
\hline & $\begin{array}{c}\text { Критерій 2. Готовність до розвитку інноваційної діяльності, що } \\
\text { базується на створених державою мотиваційних передумовах } \\
\text { для інноваційного розвитку }\end{array}$ \\
\hline & $\begin{array}{c}\text { Kритерій 3. Наявність потенційних та реальних можливостей } \\
\text { для взаємодії держави та підприємств }\end{array}$ \\
\hline \multirow[t]{4}{*}{ 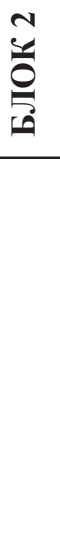 } & $\begin{array}{l}\text { Формування трьокомпонентної моделі реалізації потенціалу } \\
\text { державного регулювання інноваційної діяльності підприємств }\end{array}$ \\
\hline & $\begin{array}{c}\text { Компонент 1. Доцільність запровадження інструментів } \\
\text { державного регулювання }\end{array}$ \\
\hline & $\begin{array}{c}\text { Компонент 2. Результативність застосування інструментів } \\
\text { державного регулювання }\end{array}$ \\
\hline & $\begin{array}{c}\text { Компонент 3. Ефективність запроваджених та застосовуваних } \\
\text { інструментів державного регулювання }\end{array}$ \\
\hline 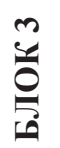 & $\begin{array}{l}\text { Обгрунтований вибір інструментарію державного регулювання } \\
\text { інноваційної діяльності відповідно до потенційних та реальних } \\
\text { можливостей суб'єктів інноваційних відносин }\end{array}$ \\
\hline
\end{tabular}

\section{Рис. 1. Методичний підхід до формування та реалізації потенціалу державного регулювання інноваційної діяльності підприсмств}

\section{Джерело: розроблено автором.}

Відповідно до БЛОКУ 1 Формування інформаційного простору для визначення компонентів потенціалу державного регулювання інноваційної діяльності підприємств повинно відбуватися на основі критеріїв наявності законодавчого та організаційно-функціонального забезпечення, готовності до розвитку інноваційної діяльності, що базується на створених державою мотиваційних передумовах для інноваційного розвитку та наявності потенційних та реальних можливостей для взаємодії держави та підприємств. Виконання зазначених критеріїв потребує теоретичного обгрунтування принципів реалізації потенціалу державного регулювання інноваційної діяльності підприємств. Принципи, завдяки яким має відбуватися формування такого потенціалу подано у табл. 1.

Наведені принципи дозволили визначити складові формування та реалізації потенціалу державного регулювання інноваційної діяльності підприємств, що лежать в основі побудови концептуальної схеми методичного підходу (рис. 2.). 


\section{Принципи реалізації потенціалу державного регулювання інноваційної діяльності підприсмств}

\begin{tabular}{|c|c|}
\hline Назва принципу & Зміст \\
\hline системності & $\begin{array}{l}\text { формування відкритої, динамічної імовірнісного характеру системи управління } \\
\text { інноваційним розвитком з урахуванням потенціалу державного регулювання }\end{array}$ \\
\hline адаптивності & $\begin{array}{l}\text { підтримання балансу зовнішніх, сформованих ринковим середовищем, і внутрішніх } \\
\text { можливостей інноваційного та фінансового розвитку суб’єкта господарювання }\end{array}$ \\
\hline самоорганізації & $\begin{array}{l}\text { самостійне забезпечення підтримки обміну різними видами ресурсів між } \\
\text { структурними складовими підприємства (зокрема, департаментами інноваційного } \\
\text { розвитку й фінансовим) та між підприємством, зовнішнім середовищем та державою }\end{array}$ \\
\hline динамічності & $\begin{array}{l}\text { динамічне приведення у відповідність цілей і спонукальних мотивів інноваційної та } \\
\text { фінансової діяльності підприємства }\end{array}$ \\
\hline саморегуляції & $\begin{array}{l}\text { коригування системи управління діяльністю інноваційним розвитком підприємства } \\
\text { відповідно до змін зовнішнього середовища в сфері державного регулювання } \\
\text { (зокрема, законодавства, умов та можливостей використання державних стимулів) }\end{array}$ \\
\hline ефективності & $\begin{array}{l}\text { зростання прибутку, розширення масштабів виробництва і можливостей } \\
\text { нагромадження капіталу, підвищенням конкурентоспроможності підприємства }\end{array}$ \\
\hline керованості & $\begin{array}{l}\text { забезпечення відповідності фактичного стану інноваційного процесу бажаному } \\
\text { (запланованому) стану після реалізації системної трансформації }\end{array}$ \\
\hline збалансованості & $\begin{array}{l}\text { інноваційні процеси і проект використання державних стимулів повинні бути } \\
\text { узгоджені у часі і термінах реалізації і являти собою єдиний процес }\end{array}$ \\
\hline вимірності & $\begin{array}{l}\text { має бути сформована система кількісних і якісних показників для оцінки } \\
\text { ефективності стратегії інноваційного росту відповідно до впровадження отриманих } \\
\text { державних стимулів }\end{array}$ \\
\hline саморозвитку & $\begin{array}{l}\text { самостійне забезпечення умов функціонування підприємства відповідно до прийнятої } \\
\text { стратегії розвитку }\end{array}$ \\
\hline невизначеності & $\begin{array}{l}\text { необхідність достовірного прогнозування і планування стратегії інноваційного росту, } \\
\text { створення фінансових резервів для зменшення можливих негативних наслідків від } \\
\text { можливих ризиків чи коректування строків виконання окремих інноваційних робіт } \\
\text { (стадій, етапів) при їхньому плануванні }\end{array}$ \\
\hline стимулювання & $\begin{array}{l}\text { забезпечення стимулюючого впливу на реалізацію інноваційних процесів } \\
\text { на підприємстві, шляхом застосування інструментів податкового регулювання }\end{array}$ \\
\hline
\end{tabular}

Джерело: сформовано автором на основі ${ }^{12} 3$

1) Цільова складова відображає мету методичного підходу до формування моделі реалізації потенціалу державного регулювання на інноваційну діяльність підприємств, яка полягає у адаптивній зміні ефективних інструментів державного регулювання та використання його потенціалу відповідно до стратегії інноваційного розвитку держави та підприємства.

2) Суб’єктивна складова показує, що розвиток інноваційної діяльності неможливий без співпраці суб'єктів цього процесу. Кожен елемент суб'єктивної складової виступає в якості складової системи інноваційних відносин. Реалізація потенціалу державного регулювання інноваційної діяльності здійснюється на макро- та мікро рівнях системи інноваційних відносин. Кожен елемент суб'єктивної складової виступає в якості складової цієї системи (рис. 3).

\footnotetext{
${ }^{1}$ Іванов, Ю. Б. (2008). Податковий менеджмент. Київ : Знання.

2 Чечель, О. (2014). Принципи та механізм державного регулювання економіки. Науковий вісник «Демократичне врядування», 13, 103-111.

${ }^{3}$ Ілляшенко, С. М. (2005). Управління інноваційним розвитком. Суми : Університетська книга.
} 


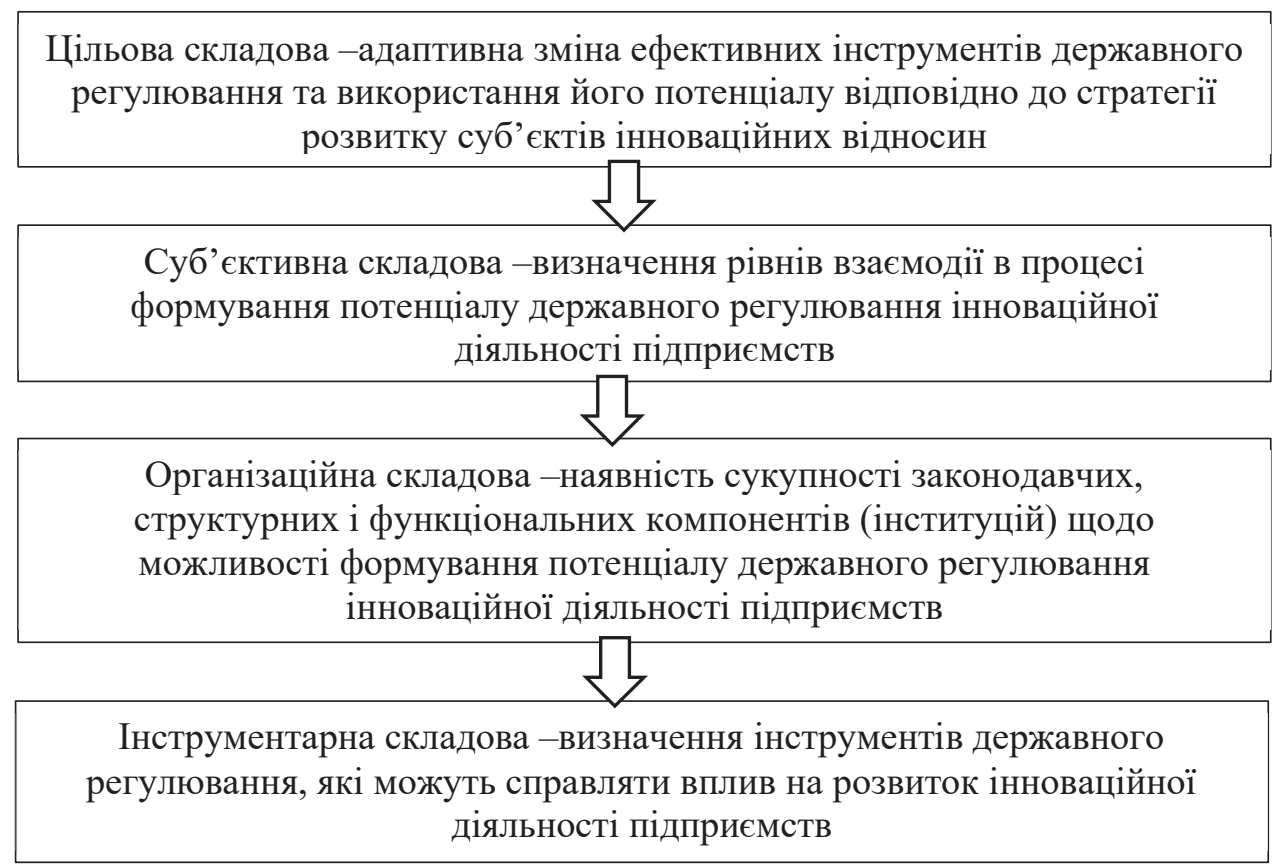

Рис. 2. Складові формування та реалізації потенціалу державного регулювання інноваційної діяльності підприємств

Джерело: розроблено автором

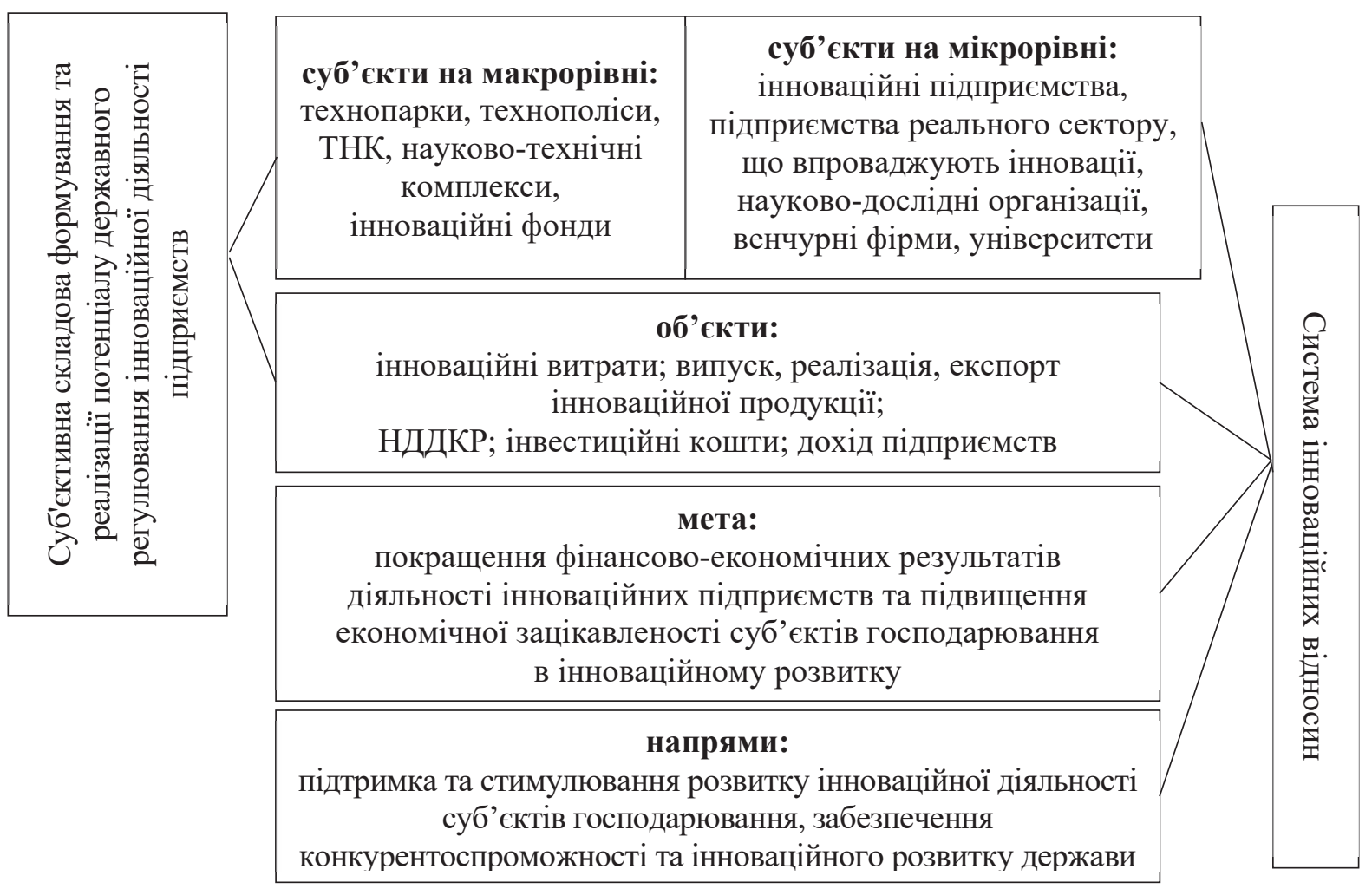

Рис. 3 Суб'єктивна складова формування та реалізації потенціалу державного регулювання інноваційної діяльності підприємств 
3) Представлені вище складові потребують законодавчого та нормативного забезпечення, що визначає зміст організаційної складової запропонованого методичного підходу. Елементи організаційної складової формування та реалізації потенціалу державного регулювання інноваційної діяльності підприємств спрямовані на забезпечення ефективної взаємодії інституцій державного регулювання у реалізації інноваційного процесу (рис. 4).

На сьогодні організаційна складова формування та реалізації потенціалу державного регулювання інноваційної діяльності працює неефективно та характеризується такими проблемами, пов'язаними з регуляторною дією законодавства в інноваційній сфері як відсутність довгострокових програм розвитку національної економіки, заснованої на інноваціях; невиконання визначених законодавством механізмів реалізації пріоритетів інноваційної діяльності та пріоритетів розвитку науки і техніки; відсутність ефективних механізмів комерціалізації результатів завершених науковотехнічних розробок, що призводить до втрати державою щорічно значних бюджетних надходжень; нерозвиненість інноваційної інфраструктури (дослідницьких університетів, технопарків, наукових парків, кластерів, високотехнологічних інноваційних підприємств, інноваційних бізнес-інкубаторів, венчурних фондів тощо.

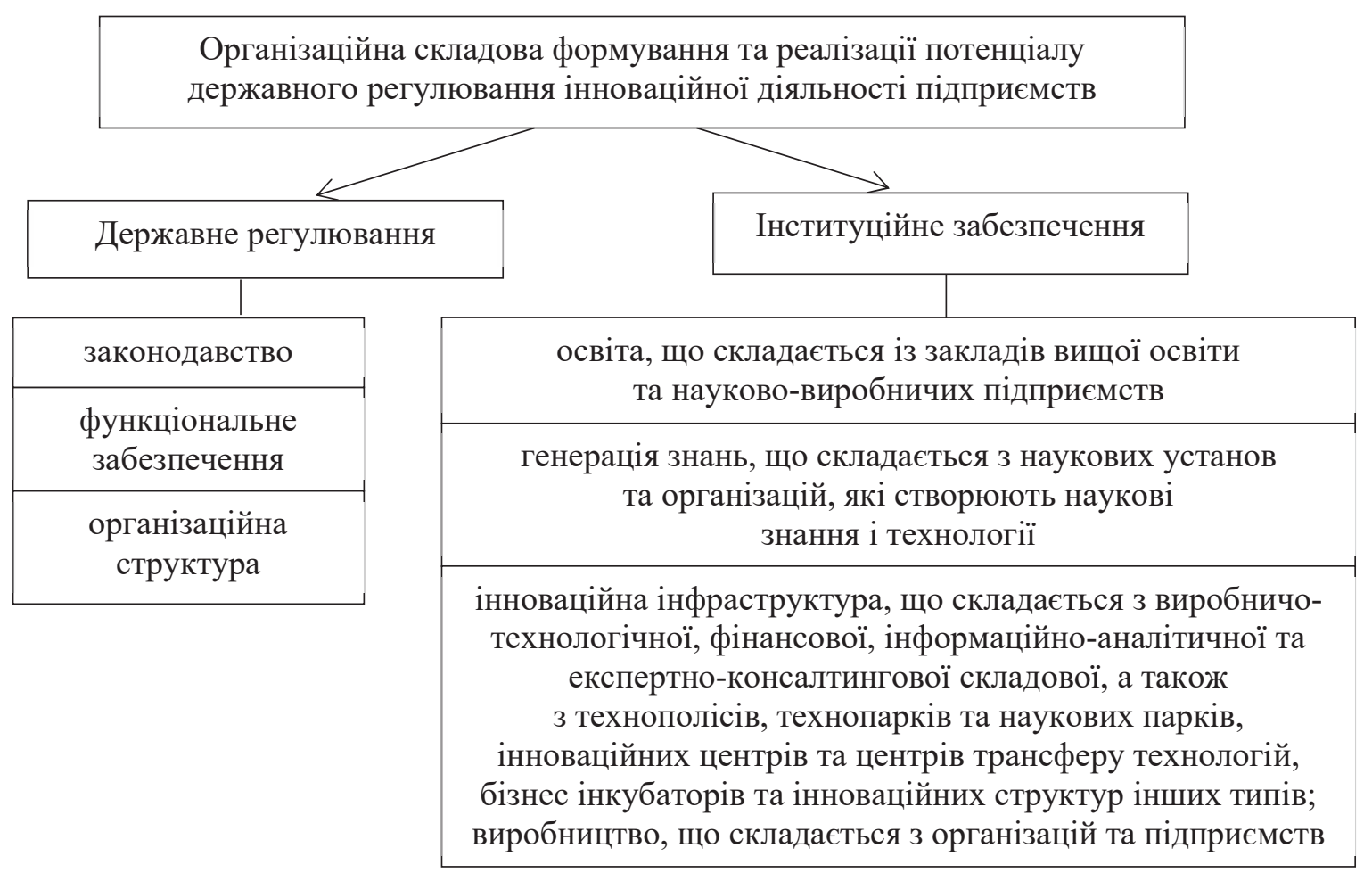

\section{Рис. 4. Організаційна складова формування та реалізації потенціалу державного регулювання інноваційної діяльності підприємств}

\section{Джерело: розроблено автором}

4) Інструментарна складова містить вибір усіх можливих ефективних та практичних інструментів державного регулювання інноваційної діяльності підприємств, що можуть бути використані в національній інноваційній системі та набувають поширення на сучасному етапі розвитку інноваційної економіки країни в цілому.

Особливості та аспекти реалізації податкових інструментів регулювання регламентовано чинною законодавчою базою. Законодавче забезпечення в інноваційній діяльності держава здійснює шляхом реалізації інноваційної політики. Застосування інструментів державного регулювання є однією 3 передумов розвитку інноваційної діяльності. За формою впливу на інноваційну діяльність держава застосовує прямі та непрямі методи, в рамках яких інструменти розподілені за певними класифікаційними ознаками. Так як єдиного підходу до класифікації немає, у табл. 2 подано узагальнену класифікацію інструментів державного регулювання інноваційної діяльності підприємств. 
Таблиця 2

\section{Узагальнення інструментів державного регулювання інноваційної діяльності підприємств}

\begin{tabular}{|c|c|c|}
\hline $\begin{array}{c}\text { Класифікаційна } \\
\text { ознака }\end{array}$ & Вид інструменту & Призначення \\
\hline \multirow{3}{*}{$\begin{array}{l}\text { За призначення } \\
\text { (напрямом } \\
\text { впливу) }\end{array}$} & $\begin{array}{c}\text { Стимулюючі } \\
\text { (заохочувальні) }\end{array}$ & $\begin{array}{l}\text { Створення мотивації підприємств до активізації діяльностей, } \\
\text { як є пріоритетними для держави }\end{array}$ \\
\hline & $\begin{array}{l}\text { Дестимулюючі } \\
\text { (стримуючі) }\end{array}$ & $\begin{array}{l}\text { Стримування діяльності тієї чи іншої галузі для уникнення } \\
\text { ефекту «перенагрівання економіки», стримування } \\
\text { виробництва шкідливої для здоров’я продукції }\end{array}$ \\
\hline & $\begin{array}{l}\text { Компенсаційні } \\
\text { (підтримуючі) }\end{array}$ & $\begin{array}{l}\text { Компенсація негативного впливу зовнішніх факторів } \\
\text { на підприємства, підтримка підприємств, які становлять } \\
\text { економічний інтерес для держави }\end{array}$ \\
\hline \multirow{2}{*}{$\begin{array}{l}\text { За характером } \\
\text { цілей соціально- } \\
\text { економічного } \\
\text { розвитку }\end{array}$} & $\begin{array}{c}\text { Стратегічні } \\
\text { (заплановані) }\end{array}$ & $\begin{array}{l}\text { Спрямування на досягнення цілей соціально-економічного } \\
\text { розвитку }\end{array}$ \\
\hline & Тактичні (оперативні) & $\begin{array}{l}\text { Спрямування на створення умов для вирішення поточних } \\
\text { цілей соціально-економічного розвитку, полягає у можливості } \\
\text { оперативно корегувати умови надання з метою забезпечення } \\
\text { ефективної реалізації регулювання }\end{array}$ \\
\hline \multirow{5}{*}{$\begin{array}{l}\text { За суб’єктами } \\
\text { НДДКР }\end{array}$} & $\begin{array}{l}\text { За сферою або } \\
\text { галуззю }\end{array}$ & $\begin{array}{l}\text { Стимулювання НДДКР в наукомістких та високотехнологічних } \\
\text { галузях (біотехнології, аерокосмічна галузь тощо) }\end{array}$ \\
\hline & За розміром & $\begin{array}{l}\text { Підприємства малого бізнесу у багатьох випадках } \\
\text { виявляються рушійною силою росту та створюються з метою } \\
\text { продукування нових ідей стосовно створення товарів, послуг, } \\
\text { процесів. Саме з цієї причини уряди багатьох країн надають } \\
\text { підтримку малому бізнесу за допомогою введення } \\
\text { спеціальних податкових режимів }\end{array}$ \\
\hline & За фазою розвитку & $\begin{array}{l}\text { Підтримка молодих науково-дослідних компаній в період їх } \\
\text { становлення }\end{array}$ \\
\hline & За видом діяльності & $\begin{array}{l}\text { Стимулювання співробітництва приватних підприємств та } \\
\text { некомерційних науково-дослідних закладів (університетів, } \\
\text { центрів, лабораторій тощо). За допомогою підтримки такого } \\
\text { співробітництва держава фактично стимулює збільшення } \\
\text { витрат приватного сектору на фундаментальні дослідження }\end{array}$ \\
\hline & За об’єктом впливу & Стимулювання підвищення кваліфікації наукових кадрів \\
\hline \multirow{3}{*}{$\begin{array}{l}\text { За механізмом } \\
\text { впливу }\end{array}$} & Системні & $\begin{array}{l}\text { Вбудовані в систему фінансової або податкової політики, } \\
\text { формують альтернативні системи оподаткування }\end{array}$ \\
\hline & Комплексні & $\begin{array}{l}\text { Включають в себе прямі і непрямі методи, формують } \\
\text { спеціальні режими стимулювання }\end{array}$ \\
\hline & Елементні (локальні) & Пов’язані з реалізацією потенціалу державного регулювання \\
\hline \multirow{3}{*}{$\begin{array}{l}\text { За сферою } \\
\text { впливу }\end{array}$} & Економічні & \multirow{3}{*}{ Вирішення завдань окремих аспектів інноваційної діяльності } \\
\hline & Соціальні & \\
\hline & Екологічні & \\
\hline \multirow{2}{*}{$\begin{array}{l}\text { За } \\
\text { функціональним } \\
\text { призначенням }\end{array}$} & Стимулюючі & Надають стимулюючий вплив на інноваційну діяльність \\
\hline & Стратегічні & $\begin{array}{l}\text { вирішення державного завдання - інноваційний розвиток } \\
\text { шляхом стимулювання інноваційної діяльності і НДДКР }\end{array}$ \\
\hline
\end{tabular}

Джерело: сформовано автором на основі ${ }^{123}$

\footnotetext{
${ }^{1}$ Петровська, І. П. (2013). Інструменти державного регулювання інноваційною діяльністю України.

Формування ринкових відносин в Україні, 5, 58-62.

${ }^{2}$ Іванов, Ю. Б., Майбуров, І. А. (2010). Податкова політика: теорія, методологія, інструментарій. Харків:

ІНЖЕК.

${ }^{3}$ Федулова, Л. І. (2006). Інноваційна економіка. Київ: Либідь.
} 
Відповідно до БЛОКУ 2 запропонованого методичного підходу доцільно розглянути процес прийняття управлінських рішень щодо реалізації потенціалу державного регулювання інноваційної діяльності шляхом формування трьокомпонентної моделі реалізації потенціалу державного регулювання інноваційної діяльності підприємств (рис. 5).

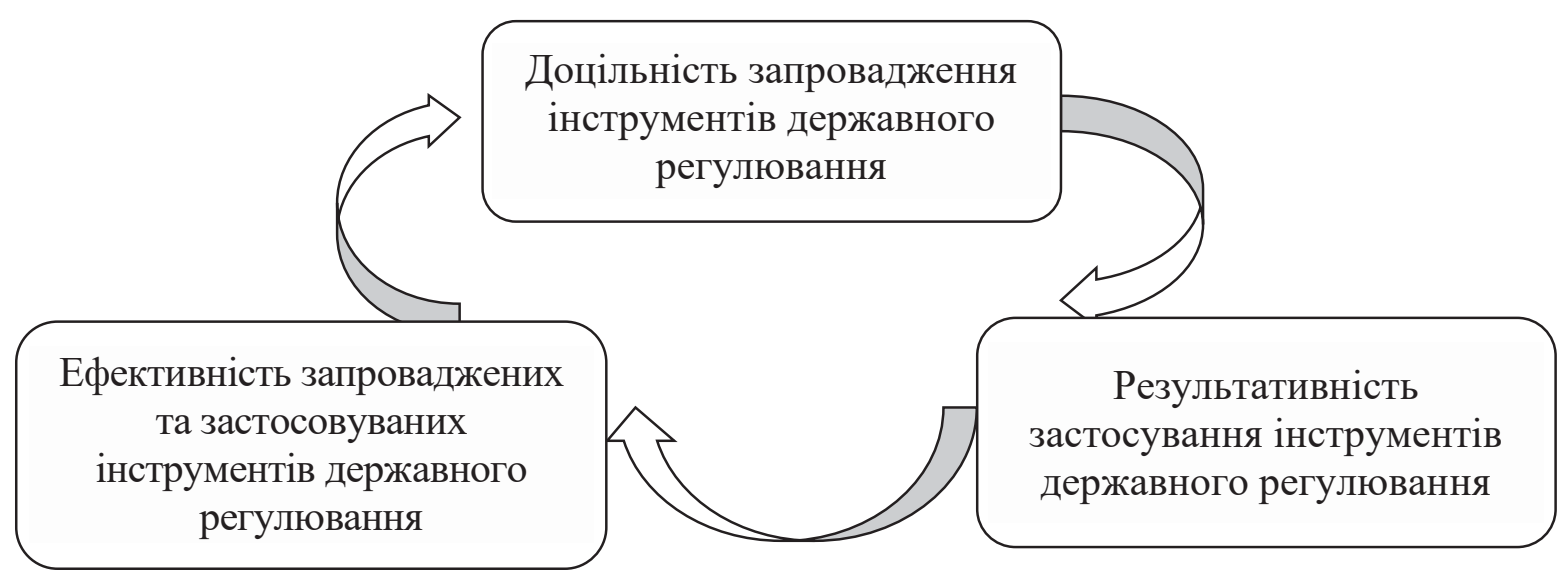
Рис. 5. Трьокомпонентна модель реалізації потенціалу державного регулювання
інноваційної діяльності підприсмств

\section{Джерело: розроблено автором}

Підсумовуючи вищезазначену модель та виходячи із наведеного в методичного підходу щодо формування та реалізації потенціалу державного регулювання інноваційної діяльності підприємств можна сформувати його компоненти: дієвість результативність та ефективність.

Автором пропонується послідовність процедури оцінки реалізації потенціалу державного регулювання і прийняття рішень за їі результатами за такими етапами:

Етап 1 - оцінка доцільності запровадження інструментів державного регулювання. Оцінюється бюджетна спроможність впровадження та надання таких інструментів як передумови державного регулювання інноваційної діяльності, що дозволить провести подальшу оцінку результативності та ефективності запроваджених податкових пільг.

Етап 2 - оцінка результативності застосування інструментів державного регулювання, що виражається у досягненні передбачуваних цільових результатів, для забезпечення яких було застосовано інструменти державного регулювання. У цьому зв'язку виникає проблема правильного кількісного вираження і вимірювання результатів за допомогою критеріїв (показників), які повною мірою характеризують цілі введення інструментів, а також достатності чи недостатності досягнутих результатів. Якщо результат від запровадження та застосування інструментів відсутній або має негативний, дестимулюючий результат, то приймається рішення про скасування або істотну зміну спрямованості інструментів регулювання. За умови достатності показника результативності проводиться оцінка ефективності.

Етап 3 - оцінка ефективності результатів: якщо іiі рівень відповідає прийнятному, нормативному, то дія інструменту регулювання продовжується на наступний період. Якщо рівень ефективності нижче прийнятного, нормативного, приймається рішення про скасування надання інструментів або їх потрібно трансформувати. Потрібно розуміти доцільність з погляду прийнятної витратності досягнення певного очікуваного і (або) запланованого результату (результатів), тобто співвідношення результату з витратами на його забезпечення.

Відповідно до БЛОКУ 3 запропонованого методичного підходу пропонується здійснювати визначення ефективного інструменту державного регулювання інноваційної діяльності підприємств відповідно до потенційних та реальних можливостей суб'єктів інноваційних відносин.

Інноваційний процес як об'єкт державного регулювання складається з декількох взаємозалежних послідовних стадій, що утворять його життєвий цикл. Через залежності характеру інноваційних витрат від стадії інноваційного процесу. Оскільки втримування цих стадій по-різному, цілком очевидно, що й інтенсивність, і методи державної підтримки інновацій повинні та їх 
інтенсивність повинні бути розподілені за етапами життєвого циклу інновацій, причому для кожного з етапів характерний свій набір мотиваційних механізмів.

Як зазначалося в інструментальній перспективі вибір інструмента податкового регулювання багато в чому залежать від об’єкта інноваційного розвитку та фази життєвого циклу інноваційної діяльності. Відповідно до запропонованого методичного підходу доцільно вибрати інструмент, який буде оптимальним з урахуванням існуючих умов:

- наявність законодавчого та організаційного забезпечення впровадження такого інструменту;

- готовність до розвитку та мотиваційна зацікавленість підприємств до здійснення інноваційної діяльності;

- можливість реалізації потенціалу державного регулювання інноваційної діяльності підприємств, що виражається у доцільному запровадженні інструментів регулювання та досягненні ними результативності та ефективності.

Висновки. Таким чином, побудовано методичний підхід до формування та реалізації потенціалу державного регулювання інноваційної діяльності підприємств відповідно до принципів та перспектив, що становлять його функціональну та організаційну структуру та дозволяє реалізовувати оптимальні інструменти податкового регулювання, як важливої складової державного регулювання, відповідно до особливостей, можливостей та умов інноваційної діяльності підприємств На основі формування структури та оцінки головних компонент реалізації потенціалу державного регулювання може бути здійснений обгрунтований вибір державою впровадження і застосування ефективного інструментарію державного регулювання інноваційної діяльності відповідно до потенційних та реальних можливостей суб'єктів інноваційних відносин.

\section{References:}

1. Ivanov, Yu. B. (2008). Podatkovyy menedzhment [Tax management]. Kyiv: Znannya. [in Ukrainian].

2. Chechel, O. (2014). Pryntsypy ta mekhanizm derzhavnoho rehulyuvannya ekonomiky [Principles and mechanism of state regulation of the economy]. Naukovyy visnyk Demokratychne vryaduvannya [Scientific bulletin Democratic governance], 13, 103-111. [in Ukrainian].

3. Illyashenko, S. M. (2005). Upravlinnya innovatsiynym rozvytkom [Management of innovative development]. Sumy: Universytetska knyha. [in Ukrainian].

4. Petrovska, I. P. (2013). Instrumenty derzhavnoho rehulyuvannya innovatsiynoyu diyalnistyu Ukrayiny [Instruments of state regulation of innovation activity of Ukraine]. Formuvannya rynkovykh vidnosyn $v$ Ukrayini [Formation of market relations in Ukraine], 5, 58-62. [in Ukrainian].

5. Ivanov, Yu. B., Maiburov, I. A. (2010). Podatkova polityka: teoriya, metodolohiya, instrumentariy [Tax policy: theory, methodology, tools]. Kharkiv: INZHEK. [in Ukrainian].

6. Fedulova, L. I. (2006). Innovatsiyna ekonomika [Innovative economy]. Kyiv: Lybid. [in Ukrainian]. 